\title{
STUDIES IN THE HISTORY OF COMPLEX FUNCTION THEORY II: INTERACTIONS AMONG THE FRENCH SCHOOL, RIEMANN, AND WEIERSTRASS
}

\author{
BY E. NEUENSCHWANDER
}

Introduction. In most of the more recent books and monographs on the history of mathematics, the chief founders of function theory, Cauchy, Riemann and Weierstrass, are contrasted with each other. It is of ten claimed, for instance, that their ideas and methods long remained without mutual influence and were entirely unified only at the beginning of the twentieth century. ${ }^{1}$ But if one consults earlier works standing somewhat closer to the time period in question, one finds them less inclined to make such claims. For example, in his Vorlesungen über die Entwicklung der Mathematik im 19. Jahrhundert, Klein characterizes Riemann as follows: "After all, any rigid one-sidedness is completely foreign to Riemann; he makes use of whatever he comes upon and applies the most diverse methods, whenever he can thereby advance and clarify his problem" $\left[59\right.$, p. 254]. ${ }^{2}$ One may thus inquire whether the above-mentioned interactions among the three function theories did not indeed begin much earlier, perhaps as far back as the time of Riemann himself, of what intensity these were at that time, and whether one can still detect specific influences on the basis of source materials from that time.

Since 1977 I have been occupied with particular aspects of these questions (see the series of articles [80 - 85]). I have been able to show, among other things, that Riemann knew and utilized the decisive works of the French mathematicians even before his promotion (cf. [85]). In this article I propose to set out the broad outlines of the interactions among the three theories and briefly to cite the most important sources in each instance. For a more detailed description of the mathematical development of the three theories, one may consult [31], [38], [59], [60], [69], [72], [78], [84], [114]; for further information on the interactions, [9], [31], [75]; and also those parts of my biography on Riemann which have already been completed. In what follows I will chiefly use the edition of selected letters from Riemann to his family (91 letters, 1836-1864, in [104]), as well as the list of Riemann's books borrowed from the University Library at Göttingen (over 500 items from 1846-1866), both to be published in my biography. ${ }^{3}$

\footnotetext{
Received by the editors November 15, 1980.

1980 Mathematics Subject Classification. Primary 01A55.

${ }^{1}$ Cf., e.g., [60, p. 669], [65, p. 194] and [69, pp. 358 f.].

${ }^{2} \mathrm{~K}$ lein relies here, presumably, on information communicated in a letter from Prym in 1882 , which arose in connection with his research on the origins of the Riemannian function theory (cf. $[58$, p. 479] and note 18$)$.

${ }^{3}$ The relevant parts are available in the form of a preprint from the author (cf. also [86]). For a photographic reproduction of a page of the University Library records of books borrowed see [87]. 
Survey of interactions. Augustin-Louis Cauchy (1789-1857), the first of the three above-mentioned founders of function theory, composed his first contribution to function theory, the Mémoire sur les intégrales définies ([15]; 1814/1827), at the age of twenty-five and went on to publish over 200 more papers in this field. The culmination of his effort here was his famous work Mémoire sur les intégrales définies, prises entre des limites imaginaires ([16]; 1825), in which he formulates with masterly precision the meaning of the definite integral between complex limits and presents the Cauchy Integral Theorem, as also his noted Turin papers ([17]; 1831-1833) on the "calcul des limites", where he treats the power series expansion of an analytic function and the Cauchy Integral Formulas for the first time. From 1840 onward Cauchy was supported by other French mathematicians in his efforts in the foundation of function theory. For instance, P. A. Laurent (1813-1854) discovered in 1843 the eponymous Laurent expansion of an analytic function in the neighborhood of an isolated singularity (cf. [18]); J. Liouville (18091882) formulated a variety of theorems within the theory of elliptic functions (cf. [81], pp. 140 f.); and V. Puiseux (1820-1883) studied in his significant paper on algebraic functions $([91] ; 1850)$ the behaviour of algebraic functions in the neighborhood of one of their branch points. The results achieved by these mathematicians were assembled for the first time by C. A. Briot (1817-1882) and J. C. Bouquet (1819-1885) in a series of articles ([12], etc.), which shortly thereafter were brought together in the extremely influential textbook Théorie des fonctions doublement périodiques et, en particulier, des fonctions elliptiques $([13] ; 1859)$. This last went through several editions and was widely adopted in Italy and Germany (cf. Appendix 2 and [81, pp. 141ff.]).

In surveying this first period of time one notes above all how long it took before the essential concepts and theorems of function theory were clearly worked out. One sees, for instance, that the Cauchy Integral Theorem was already present in Cauchy's first work from the year 1814 (but only for the case of rectangles with sides parallel to the axes and at first even only in the form of two equations between real definite integrals). For the generalization of this theorem to arbitrary closed curves one must wait until the year 1846 (cf. [19] and [20]). Moreover, in his early works Cauchy generally required merely the functions in question to be "continuous" and "finite" in a certain domain (cf. [84, pp. 61f.] and [90, pp. 467-479]); only from 1851 onwards did he recognize the importance of the existence of a derivative independent of direction. Henceforth he called functions with this property "fonctions monogènes" and showed that their real and imaginary parts must satisfy the Cauchy-Riemann differential equations (cf., e.g., [21] and [22]). Cauchy's foundation of function theory was later called into question by $\mathrm{Ch}$. Méray (1835-1911), a disciple of Briot and Bouquet. Méray, like Weierstrass, espoused the view that "continuity" is an insufficient basis for the construction of function theory and that one did better to found it on the Taylor series development of functions. In his book Nouveau précis d'analyse infinitésimale ([71]; 1872), Méray begins with a theory of the real numbers, takes up next the theory of series, and then develops function theory from the concept of power series (cf. [30], [31]). 
BERNHARD RIEMANN (1826-1866), the second of the founders of function theory, was active at Göttingen a few decades later. In his renowned dissertation Grundlagen für eine allgemeine Theorie der Functionen einer veränderlichen complexen Grösse ([95]; 1851) and in his still more famous articles on Abelian functions ([96]; 1857), Riemann, like Cauchy from 1851 onwards, proceeds from the Cauchy-Riemann differential equations for his definition of an analytic function, $f(x+i y)=u+i v$. Riemann establishes that $u$ and $v$ are potential functions and that a conformal mapping of the $x, y$-plane to the $u$, $v$-plane is effected via the analytic function $f$. Riemann next discusses the range of the minimal conditions sufficient for the determination of such a function, by means of which he is led to the formulation of the well-known Riemann Mapping Theorem. Basic to his approach are the so-called Dirichlet Principle and the Riemann surfaces.

If one poses the question as to which mathematician most strongly influenced Riemann in the elaboration of his function theory, one surely thinks at once of C. F. Gauss (1777-1855), who already possessed the essential concepts of function theory (complex integration, the Cauchy Integral Theorem, etc.) as early as $1811^{4}$ and was examiner for Riemann's dissertation and Habilitationsschrift. ${ }^{5}$ Although it is often stressed that Gauss was chronically ill toward the end of his life and increasingly cut off his contacts with the outer world, ${ }^{6}$ it nevertheless emerges from the extant sources that it was Gauss's writings that the young Riemann studied with especial zeal and from which he drew significant inspirations for his thesis. ${ }^{7}$ For instance, we read in a letter of Riemann to his father (from Berlin, March 30, 1849; [86, letter no. 43]):

Dirichlet also arranged for my admission to the Library, without there being any of the difficulties I had feared. I usually arrived around nine in the morning at the reading room to read two papers of Gauss which were nowhere else to be gotten. Another work of Gauss, which won the prize in Copenhagen, I sought in vain in the data-books of the Royal Library for a long time, but have at last received it through Dr. Galle ${ }^{8}$ of the Observatory. I am now at the point of studying it.

The last-named paper deals with Gauss's contribution to the theory of conformal mapping [40]. Riemann studied the work anew in Göttingen. If

${ }^{4}$ Cf. the letter of Gauss to Bessel on Dec. 18, 1811 in [39, vol. 10, pt. 1, pp. 365-371] = [39, vol. 8, pp. 90-92].

${ }^{5}$ Gauss's examiner's reports are in the University Archives in Göttingen, Dekanatsakten der Philos. Fakultät, no. 135 (1851-52), p. 25 and no. 137 (1853-54), p. 118. The first of these reports is published in [108, p. 375].

${ }^{6}$ Cf., e.g., [25, p. 816], [32, p. 21] and [34, pp. 318 ff.].

${ }^{7} \mathrm{Cf}$. the list of book borrowings mentioned on p. 87 and [108, pp. $369 \mathrm{ff}$.]. Incidentally, Riemann had also visited Gauss at home on a few occasions. Cf. [86, letter no. 59 (Nov. 24, 1851) and no. 63 (Sept. 28, 1852)].

${ }^{8} \mathrm{~J}$. G. Galle (1812-1910), then assistant at the Observatory, was professor of astronomy at the University in Breslau from 1851 onwards. 
one goes through the list of Riemann's books, borrowed from the University Library for the years before his promotion, one is especially struck by the entry "Gauss u. Weber Resultate aus d. Beobachtungen des magnetischen Vereins in d. Jahr. 1836-41.", for this is the only one which is repeated over the four consecutive semesters. In the journal volumes in question one finds the articles [41] and [42] of Gauss, in which Gauss develops essential theorems of potential theory and uses methods of proof analogous to the Dirichlet Principle for this purpose. ${ }^{9}$ That Riemann indeed knew the relevant proofs of Gauss, is clear from his remarks in [96, p. 97] and from the document reproduced in Appendix 1. Among the further testimonies for the influence of Gauss on Riemann, one can quote the following: a communication in a letter from Betti to Tardy, saying that Riemann got the idea of the cuts in a private conversation with Gauss [132, p. 95]; an unpublished, four-page letter from Riemann to Gauss dealing with questions from the theory of differential equations (NSUBG, Cod. MS Gauss, Briefe A: Riemann); and various statements of Klein [58, pp. 577f.] and Schering [108, pp. 369-376] on the origin of Riemann's theory of hypergeometric series etc. It is thus established that important starting points of Riemann's function theory go back in fact to the writings of Gauss. ${ }^{10}$

During his time in Berlin (1847-1849) Riemann was particularly influenced by P. G. Lejeune Dirichlet (1805-1859), G. Eisenstein (1823-1852) and C. G. J. Jacobi (1804-1851). ${ }^{11}$ Riemann attended Dirichlet's lectures on, among other things, the theory of definite integrals and partial differential equations, ${ }^{12}$ as well as those of Eisenstein and Jacobi on elliptic integrals. ${ }^{13}$ Dirichlet recognized Riemann's extraordinary talent early on and contributed considerably to the advancement of his career from that moment. In the year 1852, for example, he discussed Riemann's dissertation with him and helped him to get the literature for his Habilitationsschrift.$^{14}$ But quite early Riemann was also making himself familiar with the writings of the most important

\footnotetext{
${ }^{9}$ The same volumes also contain Gauss's article Zur Bestimmung der Constanten des Bifilarmagnetometers, on which Riemann had to report in the mathematical-physical seminar on May 22, 1851 (cf. Niedersächsische Staats- und Universitätsbibliothek Göttingen [= NSUBG], Cod. MS Riemann 26, fol. 164; 27, fol. 13 and 13, fol. 49v).

${ }^{10}$ This seems to have been asserted explicitly for the first time by Schering [108, pp. 369-376]; for a more recent mathematically oriented survey, see [78, Chapter II]. For further details, see [109, pp. 112f, 153f, 194], [113, pp. 108f.] and my article [87, notes 7, 10 and 17].

${ }^{11}$ Cf. [86, letters no. 40-43, 90].

${ }^{12} \mathrm{~A}$ list of Dirichlet's lectures in Berlin appears in [6, pp. 33-39]. In the winter of $1848 / 49$ Dirichlet lectured on the elements of the theory of series and on the general theory of forces which act according to the inverse of the square of the distances, with application to the theory of magnetism and electricity, as well as to the determination of the shape of the earth. Hattendorff emphasizes in the prefaces to [98] and [99] that Riemann based his own lectures in part on those of Dirichlet.

${ }^{13} \mathrm{~A}$ list of Jacobi's lectures is given in [64]. Riemann accompanied Eisenstein "on daily walks for a time" [86, letter no. 40; July 23, 1847] and was then occupied with the "major problem" (Hauptaufgabe) posed by Eisenstein in [37] [86, letter no. 90; Nov. 29, 1847]. But later Riemann neglected contact with Eisenstein (cf. also [55, pp. 201, 184] and [93, p. 544]).

${ }^{14} \mathrm{Cf}$. [86, letter no. 63; Sept. 28, 1852]. For further information, cf. [8, pp. 11f.], [73, p. 163], [86] and $[93$, p. 546].
} 
French mathematicians. In his first year of study 1846/47 in Göttingen, he borrowed from the University Library, among other books, the Cours d'analyse, the Calcul différentiel and the Exercices de mathématiques, all by Cauchy, along with the Traité des fonctions elliptiques of Legendre. That Riemann subsequently kept abreast with French research is shown by the University Library records of books borrowed, as well as by the draft for the defense of his doctoral work of December 16,1851, where Riemann refers to the above-mentioned papers of Cauchy ([21], [22], etc.) in connection with the definition of an analytic function.

This is the view of Cauchy, who is first and foremost among the French to have occupied himself with the theory of complex magnitudes, a view which he expressed in the session of the Paris Academy of March 31 this year on the occasion of a report on a work by Puiseux [!] and which he has pursued further in several later addresses. ${ }^{15}$

From the above it becomes clear that Riemann was suitable, as no other German mathematician then was, to effect the first synthesis of the "French" and the "German" approaches in function theory. In his introductory lectures on general complex function theory (cf. [101]-[103]; 1861), Riemann dealt with the Cauchy Integral Formulae, the operations on infinite series, the power series expansion, the Laurent series, the analytic continuation by power series (cf. the photo on p. 92), the argument principle, the product representation of an entire function with arbitrarily prescribed zeros, the evaluation of definite integrals by residues, etc., besides the subjects known from his published papers $([95]-[96]) .{ }^{16}$ Riemann's efforts in this area appear to have been acknowledged even by Weierstrass, ${ }^{17}$ and also by Koenigsberger [61, p. 421], as well as by Abbe (see Appendix 2), who heard Riemann's

\footnotetext{
${ }^{15}$ NSUBG, Cod. MS Riemann 13, fols. $100 \mathrm{f}$; the original German text appears in [85, p. 9]. In his dissertation Riemann links himself also on several conceptual matters with Cauchy (cf. [95, pp. $3 \mathrm{f}$.] and Monna [77, pp. $63 \mathrm{f}$.]). However in a later note to the dissertation (Cod. MS Riemann 13, fols. 20v, 29r, 74r; published in [95, p. 46]) he gives the $\varepsilon, \delta$-definition of continuity (not mentioned by Monna). That Riemann was already very impressed by Cauchy's work in Berlin, when he started the preparations for his dissertation, follows from an interesting story by Sylvester (cf. E. T. Bell, Men of mathematics, New York 1937, p. 490). According to this story Sylvester met in 1896 a Berlin bookseller who told him that "he was formerly a fellow pupil of Riemann, at the University, and that, one day, after receipt of some numbers of the Comptes rendus from Paris, the latter shut himself up for some weeks, and when he returned to the society of his friends, said (referring to the newly published papers of Cauchy), 'This is a new mathematic." "

${ }^{16}$ For more information on Riemann's introductory lectures on general complex function theory and his representation of the analytic continuation by power series see [85, pp. 2-7].

${ }^{17}$ In [127, pp. 7ff.] Weierstrass contrasts his position on the construction of complex function theory with those of Cauchy and Riemann and remarks in this context: "To prove the possibility of the analytic continuation Riemann was forced to have recourse to the power series, which is not carried out in his collected works, but which he did in his lectures" [127, p. 10]. From a letter from Roch to Casorati [82, p. 63; letter no. 26] it appears that Weierstrass studied Riemann's lectures at least from 1865 with the help of a set of lecture notes made by Roch (cf. [87, note 62]).
} 
3\%.

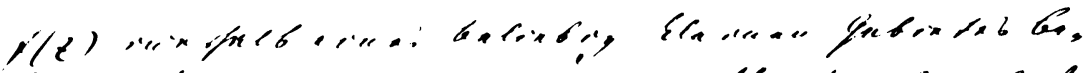

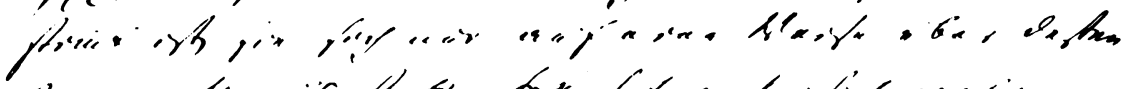

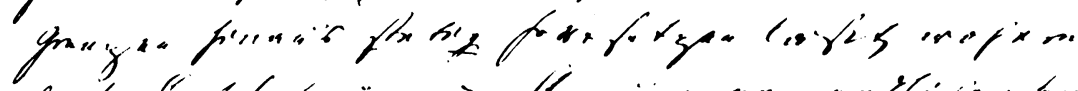

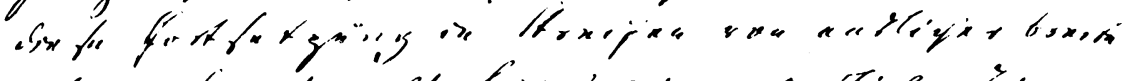

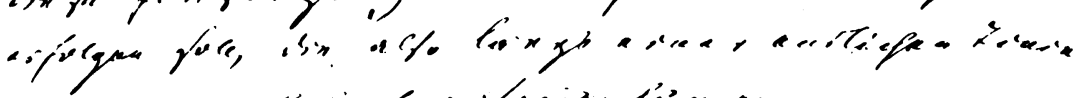

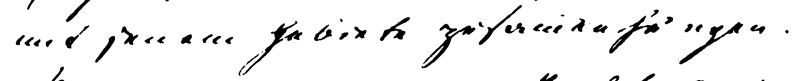

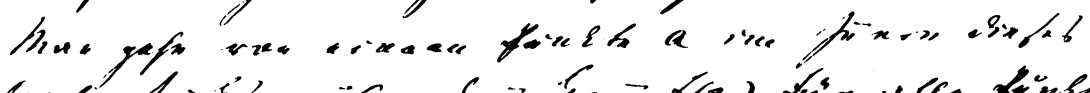

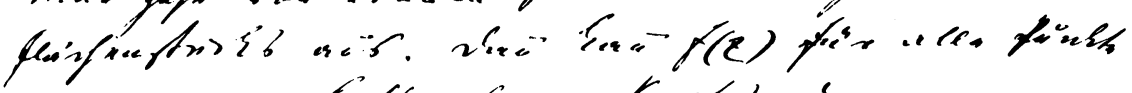

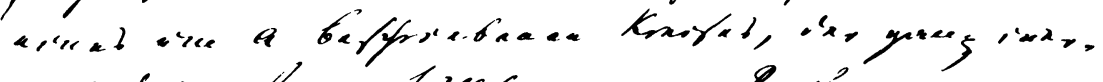

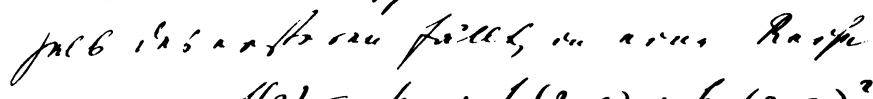

$$
f(g)=b_{0}+b_{1}(2-a)+b_{2}(8-a)^{2}+\cdots
$$

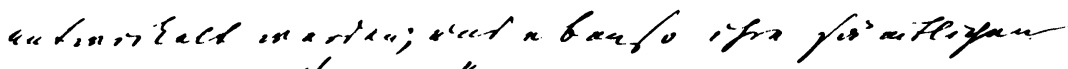

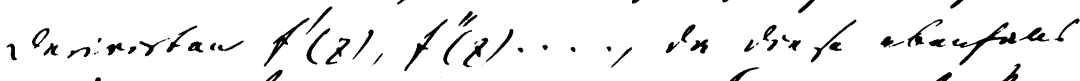

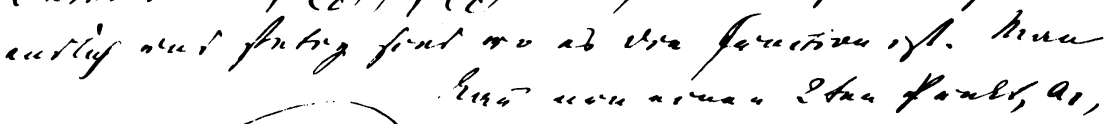

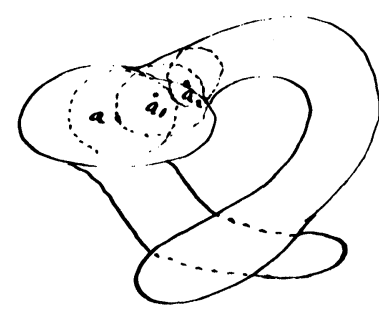

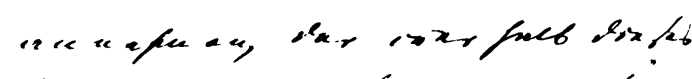

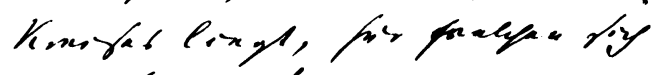

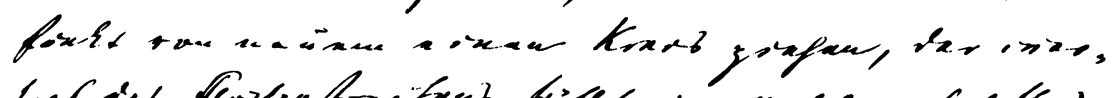

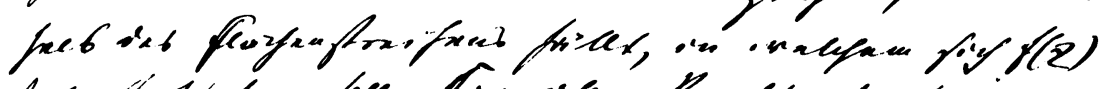

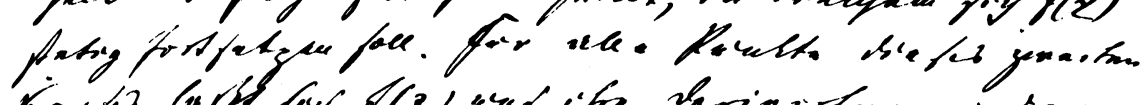

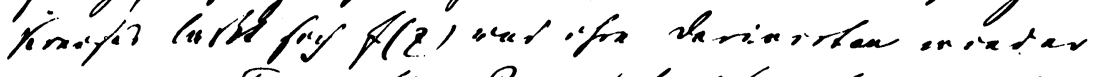

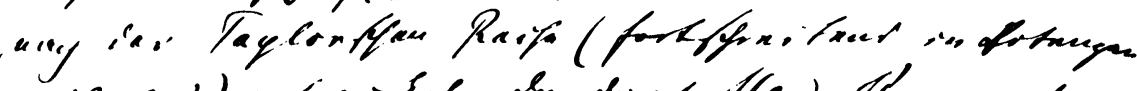

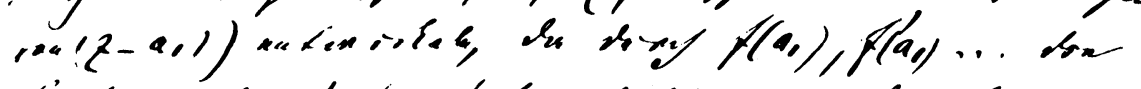

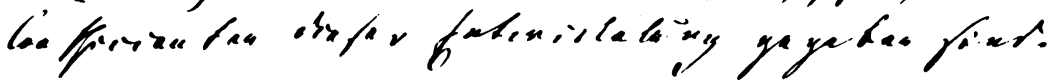

FIGURE. Riemann's treatment of analytic continuation by power series in his lectures on complex function theory [101, p. 32]. (Courtesy of Niedersächsische Staats-und Universitätsbibliothek Göttingen) 
lectures in 1861 and characterized him as one who associated himself with the "Cauchysche Manier". 18

KARL WeIERSTRASS (1815-1897), the third of the three founders of function theory, first studied public finance and administration in Bonn and then mathematics in Münster with Ch. Gudermann (1798-1852). Already during his student days in Münster he had composed three papers ([119]-[121]; 1841-42, but only first published in his collected papers in 1894) in which essential parts of his later function theory are foreshadowed. For instance, one finds here a proof of the Laurent Theorem, independent of Cauchy and discovered before Laurent; the Cauchy Estimates; the concept of uniform convergence; the definition of an analytic function by means of power series; and the principle of analytic continuation. The sources of the Weierstrassian function theory have already been investigated by several authors. ${ }^{19}$ Weierstrass himself stressed above all the great influence which $\mathbf{N}$. H. Abel (1802-1829) exerted over him $;^{20}$ on the other hand, he claims in a later annotation to his paper [121] that Cauchy's work was at that time not known to him. ${ }^{21}$ After his studies in Münster, Weierstrass was employed for several years as a relatively unknown instructor at the Gymnasium in Deutsch-Krone (1842-48) and Braunsberg (1848-55), until the sudden fame following upon his paper on the theory of Abelian functions ([116]; 1854) instigated his call to Berlin in $1856 .{ }^{22}$

In view of Weierstrass' early isolation and obscurity one would hardly suppose that before 1854 there were any significant interactions between him and Riemann. ${ }^{23}$ But around 1856 the relationship between these two mathematicians became suddenly dramatic, and there began a tense competition over the general solution of Jacobi's "inversion problem". Already in the spring of 1856 Dirichlet contrasted Riemann and Weierstrass in a letter to Kummer in Berlin. Dirichlet remarks here that Riemann had developed with great speed since his time of study in Berlin, and that for several years he had occupied himself with, among other things, the general properties of functions

\footnotetext{
${ }^{18}$ The reconstruction of the origins and starting points of Riemann's function theory given above coincides in the essential parts with statements made by Riemann's pupil Prym to Klein in the year 1882 in several letters (NSUBG, Cod. MS Klein 11, no. 382-384). For an excerpt from the nine-page letter of Prym from Feb. 6, 1882 see [87, note 19].

${ }^{19} \mathrm{Cf}$. esp. [69] and [75], which complement each other admirably. For further details see [9], [31] and the bibliography.

${ }^{20}$ Cf. [74, p. 81], [75, p. 25] and [76, p. 191].

${ }^{21}$ Mittag-Leffler ([74, p. 81] and [75, pp. 35 ff.]) takes up and sharpens Weierstrass' claim in [75] that Weierstrass only first became familiar with Cauchy's works in 1842. On the other hand, Borel emphasizes [10, p. 80] that Cauchy was at that time so well known that Weierstrass must at the very least have been indirectly influenced by him. It is quite certain that Weierstrass came to value Cauchy's works at a later period. In the list of books acquired at the newly founded mathematical seminar in Berlin in 1861, one finds in the first place five works of Cauchy (cf. [9, pp. $77 \mathrm{f}]$.$) .$

${ }^{22}$ Cf., e.g., Biermann in [3, pp. 41-52], [75, pp. 44-52], [66, pp. 29 f.] and [67, pp. 423 ff.].

${ }^{23} \mathrm{Cf}$. also Weierstrass' remark in 1859 [7, p. 28], to the effect that Riemann's dissertation had until recently remained almost wholly unknown.
} 
of a complex argument and had founded on this basis a theory of the Abelian functions which is doubtless even more comprehensive than the researches of Weierstrass. ${ }^{24}$ In the same year there appeared in Crelle's Journal a further paper by Weierstrass on Abelian functions ([117]; 1856). Riemann was aware of it already by November 2, 1856, and so hastened the preparation of his own findings. ${ }^{25} \mathrm{He}$ submitted these to Crelle's Journal in two parts, on May 18 and July 2, 1857, and there described his position with respect to the earlier works of Weierstrass in a carefully measured passage, indeed several times revised, ${ }^{26}$ as follows [96, pp. $\left.101 \mathrm{f}.\right]$ :

Jacobi's inversion problem, which is settled here, has already been solved for the hyperelliptic integrals in several ways through the persistent and regally ${ }^{27}$ successful work of Weierstrass, of which a survey has been communicated in vol. 47 of the Journ. für Math. (p. 289). Until now, however, only a part of these investigations has been fully worked out and published (vol. 52, p. 285 of the Journ. für Math.), namely the part that was outlined in $\S \S 1$ and 2 of the earlier paper and in the first half of $\$ 3$, pertaining to elliptic functions. Only after the full publication of the promised paper shall we be able to tell to what extent the later parts of the presentation agree with my article not only in the results but also in the methods leading to these.

Weierstrass consequently withdrew the third instalment of his investigations on the theory of Abelian functions, which he had in the meantime finished and submitted to the Berlin Academy. He explained this move in his collected works on the occasion of the publication of his Vorlesungen über die Theorie der Abelschen Transcendenten as follows [125, pp. 9 f.; 1902]: $:^{28}$

Already in the summer of 1857 I had submitted to the Berlin Academy a direct solution of this problem in a detailed paper. The manuscript had already been sent to the printer, but I withdrew it, for, a few weeks later, Riemann published an article on the same problem, which rested on entirely

\footnotetext{
${ }^{24}$ For the precise wording of the German text, see [8, pp. $\left.11 \mathrm{f}.\right]$.

${ }^{25} \mathrm{Cf}$. [93, p. 552]. Further details appear in unpublished letters and drafts of letters by Riemann to his brother [86, no. 77; April 25, 1857], to the student Olivier (NSUBG, Cod. MS Riemann 23/1, fol. 43) and to Borchardt (NSUBG, Cod. MS Philos. 193 ${ }^{\mathrm{m}}$, Cod. MS Riemann 19, 23/1 and $23 / 4)$. For further information see [87, note 26].

${ }^{26}$ One may infer this from the draft of a letter to Borchardt (Cod. MS Riemann 23/4, fol. 2), as well as from the drafts of the pertinent passage (ibid., $23 / 1$, fols. 42,45 , etc.).

${ }^{27}$ Literally "crowned with success". Further information on the development of Weierstrass's theory of Abelian functions can be found in a letter from Weierstrass to Schwarz dated July 8, 1872 (cf. [130]). For an excerpt from this letter see [87, note 29].

${ }^{28}$ As the printing of the volume at the time of Weierstrass' death had already progressed as far as sheet 18 , Weierstrass ought at least to have known of this passage (cf. [125, p. vi] and [66, p. 35]). On the coincidence of the solutions by Riemann and Weierstrass mentioned in this citation, see, for instance, [66, p. 35], [67, p. 429] and [62, pp. 54, 125].
} 
different foundations from mine and did not make immediately clear that it agreed completely with mine in its results. The proof for this entailed some investigations of chiefly an algebraic nature, whose execution was not altogether easy for me and made a considerable claim on my time. But after this difficulty was overcome, it seemed to me that a thoroughgoing overhaul of my paper was necessary. Other work, as well as reasons whose discussion is at present no longer of interest, then brought it about that I could only toward the end of 1869 give to the solution of the general inversion problem that form in which I have treated it from then on in my lectures.

The relationship of the two mathematicians must thus have been an extraordinary one from the very start. ${ }^{29}$ On the personal side, they appear to have understood each other quite well. Otherwise, it would scarcely be conceivable that Wilhelm Weber (1804-1891), Riemann's supporter for many years, should have proposed that Weierstrass be invited to become ordinary professor of higher mathematics at Göttingen, when Dirichlet's chair became vacant in the spring of 1859 , while at the same time Riemann was being promoted to ordinary professor of advanced theoretical astronomy and mechanics. ${ }^{30}$ Riemann, for his part, was named corresponding member of the Berlin Academy on the basis of an extremely favorable recommendation by Weierstrass ${ }^{31}$ and travelled to Berlin in the company of Dedekind in September of 1859 to accept the nomination. As the existing sources indicate, they were received with great warmth, including an invitation to dine with Weierstrass. ${ }^{32}$ According to Mittag-Leffler, Weierstrass on several occasions characterized Riemann as an "anima candida" [76, p. 191], and according to Runge he is even alleged to have said that he "had loved Riemann like a brother" [105, p. 179].

On the professional side, the mutual influence was unquestionably great. It would be entirely conceivable that the general systematic construction of the Weierstrassian function theory, achieved around 1860, as P. Dugac has

\footnotetext{
${ }^{29}$ Weierstrass apparently never quite got over having withdrawn his work from publication, as several passages from his correspondence with Sonya Kovalevskaya indicate. For instance, Weierstrass cites in a letter to her a communication from an earlier letter of Richelot, in which Richelot expresses his regret that Weierstrass had not published that work at that time (letter of Aug. 20,1873 in [63, p. 28] $=[76$, p. 142]). In a later letter Weierstrass indicates his intention to summarize his investigation of Abelian functions in a series of letters to Richelot, since in this way he "could freely call attention to the characteristic of his method, and also bring in a critique of those used by Riemann and Clebsch" (letter of Jan. 12, 1875 in [63, p. 62] = [76, p. 159]).

${ }^{30} \mathrm{On}$ this unsuccessful invitation, renewed in later years, see [32, pp. 131 f., 168, $180 \mathrm{ff}$., $186 \mathrm{f}$.], where extracts from the pertinent official papers are published.

${ }^{31}$ Cf. [7, pp. 27-29].

${ }^{32}$ Cf., e.g., [93, p. 554], [66, pp. 35 f.], [67, p. 430] and [32, p. 284]. In connection with that meeting, Riemann sent Weierstrass the letter, of which an extract was later published in [97]. For further details see [87, note 33].
} 
determined [31, pp. $53 \mathrm{ff}.]{ }^{33}$ could have been inspired by, among other things, the works of Riemann pertaining to the same set of ideas. ${ }^{34}$ While Riemann freely employed the methods of others (cf. p. 87) and also took these up in his lectures (cf. [85] and Appendix 2), by contrast, Weierstrass seems to have admitted them into his theory usually only after a systematic reworking. ${ }^{35}$ Thus, for example, Koenigsberger complains in his report on the lectures of Weierstrass that they hardly included anything of the numerous discoveries of Cauchy $[61, \text { p. } 421]^{36}$ and, in another place, that the younger mathematicians of the time all had the feeling that the viewpoints and methods of Riemann no longer belonged to the rigorous mathematics of Euler, Lagrange, Gauss, Jacobi, Dirichlet, and others [62, p. 54].

After Riemann's death Weierstrass attacked his methods quite often, in part even openly. On July 14, 1870 he read his now famous critique on the Dirichlet Principle before the Royal Academy of Sciences in Berlin [122]. ${ }^{37}$ Weierstrass there showed by means of a simple example from the calculus of variations that there did not always exist a function among those admitted such that the expression in question attained the lower bound, as Riemann had assumed. In this way, one of the bases of Riemann's function theory was called into question. As a result, many mathematicians abandoned Riemann's method or sought to prove his results by other means. ${ }^{38}$

A further major objection against Riemann's function theory was formulated by Weierstrass in a letter to H. A. Schwarz on Oct. 3, 1875. In this writing, later published among his collected works, Weierstrass remarks [124, p. 235]: ${ }^{39}$

... The more I think about the principles of function theory - and I do this without cease - the firmer becomes my conviction that this must be based on the foundation of algebraic truths and that, consequently, it is not the right

\footnotetext{
${ }^{33}$ Cf. also [61, p. 421], [62, p. 51] and note 27.

${ }^{34} \mathrm{Cf}$., for instance, the title of [95]. For other possible influences of Riemann on Weierstrass, see [58, p. 578] and [97]; for influences from other mathematicians, see [33, p. 8].

${ }^{35}$ Cf. Weierstrass' own words on p. 96 ; [105, p. 178], [59, p. 284] and [58, pp. 573, 579 f.]. In the last of these Klein outlines the three different versions of the dissertation of Schottky, until the form desired by Weierstrass was reached.

${ }^{36}$ Cf. also [105, p. 177].

${ }^{37}$ The claim which one sometimes meets in the literature [59, p. 263], etc. that Weierstrass had already published his contribution [122] in 1869 rests on a confusion with ([110]; 1869), in which there appears the first published critique of the Dirichlet Principle. Weierstrass made his delivery only on July 14, 1870. In the Monatsberichte der Königl. Preussischen Akademie der Wissenschaften zu Berlin from 1870 there appears the note (p. 575): "14 July. General session of the Academy. Mr. Weierstrass read 'Remarks on the so-called Dirichlet Principle' ".

${ }^{38}$ Cf. [82, pp. 21-35] and the letter of Thieme of March 30, 1878 (reproduced in [87, part 3]).

${ }^{39}$ Weierstrass expressed similar thoughts in an address before the Berlin Mathematical Seminar on May 28, 1884, but published in [127] only after his death. In it he is especially thorough in contrasting his position on the construction of function theory with those of Cauchy and Riemann.
} 
way if, instead of building on simple and fundamental algebraic theorems, one appeals to the "transcendental", to express myself briefly - however seductive upon first glance, for instance, those ways of thinking might be, by which Riemann has discovered so many of the most important properties of algebraic functions. (That any route must be permitted to the researcher during the period of seeking is self-evident; what is at issue here is merely the systematic foundation.)

After having put forward this my creed of faith, in which I have been confirmed especially through an exhaustive study of the theory of the analytic functions of several variables...

Moreover Weierstrass went on to criticize or extend various theorems and concepts of Riemann from real analysis. For instance, in connection with the continuous, "nondifferentiable" function

$$
\sum_{n=1}^{\infty} \frac{\sin \left(n^{2} x\right)}{n^{2}}
$$

which Riemann is alleged to have given without proof (the complete treatment of the Riemannian function was obtained only in 1971 [111]) ${ }^{40}$, he developed his own now-famous continuous, nowhere differentiable function ([123]; 1872/1895). In 1885 Weierstrass criticized further Riemann's concept of the integral, in letters to P. du Bois-Reymond [126, pp. 214-219], Sonya Kovalevskaya $([76$, p. 196] $=[63$, p. 124]) and H. A. Schwarz [31, p. 141]; he deemed it "insufficient" (unzulänglich) and not general enough, ${ }^{41}$ only to cite some further examples. ${ }^{42}$

In comparison with the Weierstrassian function theory, built on strictly arithmetical foundations, the Riemannian theory, still operating in part with intuition and unproven limiting procedures, was in a truly difficult position. ${ }^{43}$ During its heyday (1870-1890) the Weierstrassian school took over nearly every position in Germany, for instance with H. A. Schwarz in Göttingen. ${ }^{44}$ Only with the works of Klein [58] and the rehabilitation of the Dirichlet Principle by Hilbert ([53]-[54]) could the Riemannian theory again gradually

\footnotetext{
${ }^{40}$ For further information see [83, translated by $\mathrm{H}$. Edwards from a German draft-version] and the later published Appendix [87, note 42, Nachtrag] to it. From an excerpt of a letter from $\mathbf{H}$. A. Schwarz to Weierstrass reproduced in [87, note 42], it appears that Weierstrass could have presented his example to the Academy in 1872 as a consequence of a suggestion of Schwarz.

${ }^{41}$ Cf. [47, pp. 67-70].

${ }^{42}$ For additional examples see: [126, p. 207] (Riemann's concept of the real function); [118, p. $210]$ and [130, letter of Dec. 20, 1880] (concept of the analytic function); [130, letter of Dec. 20, 1874] (proof of the Cauchy Integral Theorem); [31, pp. 88f.] (Riemann surfaces); [63, p. $31]=[76$, p. 143] (theory of linear differential equations).

${ }^{43}$ Cf., e.g., [32, pp. 18 f.], [59, p. 286], [67, pp. 428 ff.], [75, p. 50], [89, p. 7] and [127].

${ }^{44} \mathrm{~A}$ survey of the Weierstrassian school is given by Behnke in [3, pp. 35-40]. For further information, cf. the compilation of promotions in [9, pp. 237-245].
} 
recover from the blow delivered it by Weierstrass. ${ }^{45}$ About 1900 , after Goursat had shown the complete equivalence between the class of functions which are holomorphic in the Riemannian sense and the class of those holomorphic in the Weierstrassian sense [45], the two rival approaches were again unified little by little, thanks to the efforts of Goursat [46], Bieberbach [5], Courant [24] and others. ${ }^{46}$

\section{APPENDICES}

Appendix 1: Riemann on the Dirichlet Principle. The extract given below comes from an unpublished draft of a letter of Riemann with many erasures and revisions, parts of it difficult to decipher (NSUBG, Cod. MS Riemann 3, fol. 62v). The draft was probably written about $1855-60$, as one can see from a list of participants in Riemann's lectures on the same sheet, and from a salutation (ibid., fol. 66r, top). Of special importance is a reference in it to the papers of Kirchhoff and Thomson, which are not mentioned in Riemann's printed articles ([95, pp. 30f], [96, p. 97]). Also noteworthy is a remark, omitted below, of Dirichlet [?] which Riemann added in the margin, to the effect that Riemann's "treatment of multivalued functions is to be preferred to the prevailing one of Cauchy and Puiseux [Puiseux is erased in the manuscript], and that it leads much further" (ibid., fol. 62v, below). For the original German text see [87, note 10]; for more information on the history of the Dirichlet Principle [78] and [82, pp. 21-33].

I have denoted by the name "Dirichlet's principle" a method proving that a function is completely determined by a partial differential equation and suitable linear boundary conditions, i.e. that the problem to determine a function satisfying these conditions has one, and only one, solution. This method was applied by William Thomson in his paper Sur une équation aux différences (Liouville, vol. 12, p. 493) and by Kirchhoff in his paper on the vibrations of an elastic disc, after Gauss had applied a similar method earlier to a problem that can be considered as a special case of the latter problem (Allgemeine Lehrsätze, Art. 29-34). I have named this method after Dirichlet because Professor Dirichlet informed me that he has been using the method in his lectures 〈since the beginning of the 1840's (if I'm not mistaken) [fol. 66r] $\rangle$

Appendix 2: AbBe on the Lectures of Riemann and Weierstrass. For several years the well-known physicist Ernst Abbe (1840 - 1905, see [1]), the

\footnotetext{
${ }^{45} \mathrm{Cf}$., e.g., [5, p. 51] and [25, pp. 817, 1272]. A good sketch of the two theories, together with a detailed bibliography, is given in [56].

${ }^{46} \mathrm{Cf}$. [46, preface], [4, preface], [5, pp. 48 ff.], [72, vol. II, pt. 3, pp. 382 ff.], [3, p. 29] and [9, pp. $110,79 \mathrm{f}$.]. Bieberbach's statement [5, pp. 48, 51] that Weierstrass's pupil H. A. Schwarz was one of the first to contribute towards a reconciliation of the two rival approaches can also be substantiated by some documents on the personal relations between Schwarz and the Riemann family (cf. [87, note 48]).
} 
founder of the Carl-Zeiss-Foundation at Jena, had an extensive correspondence with Harald Schütz, a student of mathematics and later a high school teacher, whom he had gotten to know while studying at Göttingen. At Easter 1861 Schütz went from the University of Göttingen to the University of Berlin, and from then on the two friends used to report on the lectures at the two universities, often exchanging their notes. In a letter dated May 6, 1861 (University Library of Jena, Letters of E. Abbe to H. Schütz, no. 20), of which an excerpt will be given below, Abbe first summarizes the lectures of Riemann on general function theory (cf. [101]) up to that date, and then contrasts the presentation of Riemann with that of Weierstrass. He states in this connection that the method of Riemann is related to that of Briot and Bouquet (cf. [13]), while the presentation of Weierstrass is based on the work of Ch. Gudermann (the teacher of Weierstrass) and Jacobi. The letter reproduced below is one of the first documents concerning the interaction between Riemannian and Weierstrassian function theory. For the original German text with an extensive commentary, and for more excerpts from the correspondence between Abbe and Schütz, see [87, part 2]. For other documents concerning the early interaction compare [87, part 3] and [82, Appendix II, pp. 73-80].

Concerning your wish regarding the Riemannian elliptic functions, I don't believe that you can expect any help from here. During these 14 days Riemann did not say $a$ word about elliptic functions: absolutely nothing directly concerning this subject. Rather, he is still dealing with quite general theories, and it will probably be a long time before he comes to the elliptic functions. Until now he has taught the theory of functions of complex variables, - the geometrical representation of these functions, - the operations on them, - the integration through complex values, - the expansion in series and the conditions of their convergence. All this pertains to the peculiar way in which he will afterwards develop the theory of elliptic and Abelian functions (as special applications of the general theory). On the other hand, if Weierstrass referred you to Gudermann, it follows that he bases himself in his lectures on Jacobi's method of treating elliptic functions, which starts from quite different foundations. Besides, I believe, if Weierstrass really presupposes a complete knowledge of this theory, that you will not have much advantage from his course, and that you will do better by first learning this theory for yourself at leisure, either privatim or by waiting for a more suitable course of lectures. - If you want to do this, I shall send you my Briot and Bouquet, although in this book the subjects are presented in the manner of Cauchy (whom Riemann too follows), but which will probably be useful to you. (I don't need it, because here several others possess it too, so that I can have it from them if I should need it). 
ACKNOWLEDgments. The present research was carried out during a one year's stay at Harvard. An extended version including all the source material will appear in German [87]. I wish to thank the Department of the History of Science at Harvard University for its hospitality, the Niedersächsische Staats-und Universitätsbibliothek Göttingen (= NSUBG), the Staatsbibliothek Preussischer Kulturbesitz Berlin and the Universitätsbibliothek Jena for the permission to publish the source material, and above all Professor Wilbur Knorr for his generous support in translating this paper.

\section{REFERENCES}

1. F. Auerbach, Ernst Abbe. Sein Leben, sein Wirken, seine Persönlichkeit, Akademische Verlagsgesellschaft, Leipzig, 1918.

2. M. Bacharach, Abriss der Geschichte der Potentialtheorie, Vandenhoeck \& Ruprecht, Göttingen, 1883.

3. H. Behnke and K. Kopfermann, (eds.), Festschrift zur Gedächtnisfeier für Karl Weierstraß. 1815-1965, Westdeutscher Verlag, Köln und Opladen, 1966.

4. L. Bieberbach, Lehrbuch der Funktionentheorie. Band I. Elemente der Funktionentheorie, Teubner, Leipzig und Berlin, 1921.

5. __ Hermann Amandus Schwarz, Sitzungsber. Berliner Math. Gesellschaft 21 (1922), 47-52.

6. K.-R. Biermann, Johann Peter Gustav Lejeune Dirichlet. Dokumente für sein Leben und Wirken, Abh. Deutsch. Akad. Wiss. Berlin, K1. Math. Phys. Tech., Jahrgang 1959, no. 2.

7. __, Vorschläge zur Wahl von Mathematikern in die Berliner Akademie, Abh.

Deutsch. Akad. Wiss. Berlin, Kl. Math. Phys. Tech., Jahrgang 1960, no. 3.

8. _ Zu Dirichlets geplantem Nachruf auf Gauß, NTM-Schr. Geschichte Naturw. Tech. Medizin 8 (1971), 9-12.

9. __ Die Mathematik und ihre Dozenten an der Berliner Universität 1810-1920. Stationen auf dem Wege eines mathematischen Zentrums von Weltgeltung, Akademie-Verlag, Berlin, 1973.

10. E. Borel, Lecons sur la théorie des fonctions, Gauthier-Villars, Paris, 1898.

11. A. Brill and M. Noether, Die Entwicklung der Theorie der algebraischen Functionen in älterer und neuerer Zeit, Jahresber. Deutsch. Math.-Verein. 3 (1892/93), 107-566.

12. C. Briot and J. Bouquet, Étude des fonctions d'une variable imaginaire, J. École Impériale Polytechnique, cahier 36, 21 (1856), 85-131.

13. Théorie des fonctions doublement périodiques et, en particulier, des fonctions elliptiques, 1st ed., Mallet-Bachelier, Paris, 1859; 2nd ed., Théorie des fonctions elliptiques, Gauthier-Villars, Paris, 1875; German Translation: Briot und Bouquet's Theorie der doppelt-periodischen Functionen und insbesondere der elliptischen Transcendenten mit Benutzung dahin einschlagender Arbeiten deutscher Mathematiker dargestellt von Hermann Fischer, Schmidt, Halle, 1862.

14. F. Casorati, Teorica delle funzioni di variabili complesse, Fusi, Pavia, 1868.

15. A.-L. Cauchy, Mémoire sur les intégrales définies (presented 1814, submitted to the press 1825), Mémoires présentés par divers Savans à l'Académie des Sciences de l'Institut de France 1 (1827), 599-799 = Oeuvres (1), vol. 1, 329-506.

16. __ Mémoire sur les intégrales définies, prises entre des limites imaginaires, Paris, 1825 = Oeuvres (2), vol. 15, 41-89.

17. __ Extrait du mémoire présenté à l'Académie de Turin le 11 octobre 1831, Turin, $1832 / 33$ = Oeuvres (2), vol. 15, 262-411.

18. __ Rapport sur un Mémoire de M. Laurent, qui a pour titre: Extension du théorème de $M$. Cauchy relatif $\grave{a}$ la convergence du développement d'une fonction suivant les puissances ascendantes de la variable $x$, C. R. Acad. Sci. 17 (1843), 938-940 = Oeuvres (1), vol. 8, 115-117.

19. Sur les intégrales qui s'étendent à tous les points d'une courbe fermée, C. R. Acad. Sci. 23 (1846), 251-255 = Oeuvres (1), vol. 10, 70-74. 
20. Considérations nouvelles sur les intégrales définies qui s'étendent à tous les points d'une courbe fermée, et sur celles qui sont prises entre des limites imaginaires, C. R. Acad. Sci. 23 (1846), 689-702 = Oeuvres (1), vol. 10, 153-168.

21. __ Sur les fonctions de variables imaginaires, C. R. Acad. Sci. 32 (1851), 160-162 = Oeuvres (1), vol. 11, 301-304.

22. __ Sur les fonctions monotypiques et monogènes, C. R. Acad. Sci. 32 (1851), 484-487 = Oeuvres (1), vol. 11, 376-380.

23. A. Clebsch and P. Gordan, Theorie der Abelschen Functionen, Teubner, Leipzig, 1866.

24. R. Courant and A. Hurwitz, Vorlesungen über allgemeine Funktionentheorie und elliptische Funktionen von Adolf Hurwitz. Herausgegeben und ergänzt durch einen Abschnitt über geometrische Funktionentheorie von $\boldsymbol{R}$. Courant, Springer, Berlin, 1922.

25. R. Courant, Bernhard Riemann und die Mathematik der letzten hundert Jahre, Die Naturwissenschaften 14 (1926), 813-818, 1265-1277.

26. __ Dirichlet's Principle, conformal mapping, and minimal surfaces, Interscience, New York, 1950.

27. P. G. Lejeune Dirichlet, Gedächtnissrede auf Carl Gustav Jacob Jacobi, Arch. Math. Phys. 22 (1854), 158-182.

28. __ Vorlesungen über die im umgekehrten Verhältniss des Quadrats der Entfernung wirkenden Kräfte. Herausgegeben von Dr. F. Grube, Teubner, Leipzig, 1876.

29. P. Du Bois-Reymond, Die allgemeine Functionentheorie, Laupp, Tübingen, 1882.

30. P. Dugac, Charles Méray (1835-1911) et la notion de limite, Rev. Histoire Sci. 23 (1970), 333-350.

31. __ Éléments d'analyse de Karl Weierstrass, Arch. Hist. Exact Sci. 10 (1973), 41-176.

32. __ Richard Dedekind et les fondements des mathématiques, Vrin, Paris, 1976.

33. __ Problèmes de l'histoire de l'analyse mathématique au XIXème siècle, cas de Karl Weierstrass et de Richard Dedekind, Historia Math. 3 (1976), 5-19.

34. G. W. Dunnington, Carl Friedrich Gauss: titan of science, Exposition, New York, 1955.

35. H. Durège, Elemente der Theorie der Functionen einer complexen veränderlichen Grösse, Teubner, Leipzig, 1864.

36. W. Ebel, Catalogus Professorum Gottingensium 1734-1962, Vandenhoeck \& Ruprecht, Göttingen, 1962.

37. G. Eisenstein, Aufgaben und Lehrsätze, J. Reine Angew. Math. 35 (1847), 275-276 = Math. Abh. (Reimer, Berlin, 1847), 335-336 = Math. Werke (Chelsea, New York, 1975), vol. 2, 503-504.

38. H. Freudenthal, Riemann, Georg Friedrich Bernhard, Dictionary of Scientific Biography, vol. 11, Scribner, New York, 1975, pp. 447-456.

39. C. F. Gauss, Werke, 12 vols., Göttingen, Gotha, Leipzig and Berlin, 1863-1933.

40. __ Allgemeine Auflösung der Aufgabe: die Theile einer gegebnen Fläche auf einer andern gegebnen Fläche so abzubilden, daß die Abbildung dem Abgebildeten in den kleinsten Theilen ähnlich wird, Astronom. Abh. (Schumacher ed.), 3 (1825), 1-30 = [39], vol. 4, 189-216.

41. Allgemeine Theorie des Erdmagnetismus, Resultate aus den Beobachtungen des magnetischen Vereins im Jahre 1838, 1-57, 146-148 = [39], vol. 5, 119-193.

42. __ Allgemeine Lehrsätze in Beziehung auf die im verkehrten Verhältnisse des Quadrats der Entfernung wirkenden Anziehungs-und Abstossungskräfte, Resultate aus den Beobachtungen des magnetischen Vereins im Jahre 1839, 1-51 = [39], vol. 5, 195-242.

43. H. Geppert, Über Gauss' Arbeiten zur Mechanik und Potentialtheorie, [39], vol. 10, pt. 2, Abh. 7.

44. Ch. C. Gillispie, Dictionary of scientific biography, Scribner, New York, 1970-1978.

45. É. Goursat, Sur la définition générale des fonctions analytiques, d'après Cauchy, Trans. Amer. Math. Soc. 1 (1900), 14-16.

46. ___ Cours d'analyse mathématique, vol. 2, Gauthier-Villars, Paris, 1905.

47. Th. Hawkins, Lebesgue's theory of integration. Its origins and development, University of Wisconsin Press, Madison, Wis., 1970.

48. L. Heffter, Begründung der Funktionentheorie auf alten und neuen Wegen, Springer, Berlin, Göttingen and Heidelberg, 1955.

49. E. Heine, Ueber trigonometrische Reihen, J. Reine Angew. Math. 71 (1870), 353-365. 
50. , Ueber einige Voraussetzungen beim Beweise des Dirichlet'schen Principes, Math. Ann. 4 (1871), 626-632.

51. _ Die Elemente der Functionenlehre, J. Reine Angew. Math. 74 (1872), 172-188.

52. D. Hilbert, Zum Gedächtnis an Karl Weierstraß, Nachrichten von der Königl. Gesellschaft der Wissenschaften zu Göttingen, Geschäftliche Mittheilungen aus dem Jahre 1897, pp. 60-69.

53. , Uber das Dirichlet'sche Princip, Jahresber. Deutsch. Math.-Verein. 8 (1900), 184-188 = Gesammelte Abh., vol. 3, 10-14.

54. , Über das Dirichletsche Prinzip, Math. Ann. 59 (1904), 161-186 = Gesammelte Abh., vol. 3, 15-37.

55. A. Hurwitz and F. Rudio, Briefe von G. Eisenstein an M. A. Stern, Z. Math. Phys. 40 (1895), Supplement, 169-203.

56. A. Hurwitz, Über die Entwickelung der allgemeinen Theorie der analytischen Funktionen in neuerer Zeit, Verhandlungen des ersten internationalen Mathematiker-Kongresses (Zürich, 1897), Teubner, Leipzig, 1898, pp. 91-112.

57. O. D. Kellogg, Foundations of potential theory, Springer, Berlin 1929.

58. F. Klein, Gesammelte Mathematische Abhandlungen, vol. 3, Springer, Berlin, 1923.

59. __ Vorlesungen über die Entwicklung der Mathematik im 19. Jahrhundert. Teil I. Für den Druck bearbeitet von R. Courant und O. Neugebauer, Springer, Berlin, 1926.

60. M. Kline, Mathematical thought from ancient to modern times, Oxford University Press, New York, 1972.

61. L. Koenigsberger, Weierstraß' erste Vorlesung über die Theorie der elliptischen Funktionen, Jahresber. Deutsch. Math.-Verein. 25 (1917), 393-424.

62. , Mein Leben, Winter, Heidelberg, 1919.

63. P. Kotschina-Polubarinowa, Briefe von Karl Weierstrass an Sofie Kowalewskaja, 18711891, Nauka, Moscow, 1973. (Russian and German)

64. L. Kronecker, Verzeichniss der Vorlesungen, welche Jacobi an den Universitäten zu Berlin und Königsberg gehalten hat, in: C. G. J. Jacobi, Gesammelte Werke, vol. 7, Reimer, Berlin, 1891, pp. 409-412 = J. Reine Angew. Math. 108 (1891), 332-334.

65. G. Kropp, Geschichte der Mathematik. Probleme und Gestalten, Quelle \& Meyer, Heidelberg, 1969.

66. E. Lampe, Karl Weierstraß, Jahresber. Deutsch. Math.-Verein. 6 (1897), 27-44.

67. Zur hundertsten Wiederkehr des Geburtstages von Karl Weierstraß, Jahresber. Deutsch. Math.-Verein. 24 (1915), 416-438.

68. W. Lorey, Das Studium der Mathematik an den deutschen Universitäten seit Anfang des 19. Jahrhunderts, Teubner, Leipzig und Berlin, 1916.

69. K. R. Manning, The emergence of the Weierstrassian approach to complex analysis, Arch. Hist. Exact Sci. 14 (1974/75), 297-383.

70. A. I. Markuschewitsch, Skizzen zur Geschichte der analytischen Funktionen, VEB Deutscher Verlag der Wissenschaft, Berlin, 1955.

71. Ch. Méray, Nouveau précis d'analyse infinitésimale, Savy, Paris, 1872.

72. W. F. Meyer (ed.), Encyklopädie der mathematischen Wissenschaften mit Einschluss ihrer Anwendungen, Teubner, Leipzig, 1898-1935.

73. H. Minkowski, Peter Gustav Lejeune Dirichlet und seine Bedeutung für die heutige Mathematik, Jahresber. Deutsch. Math.-Verein. 14 (1905), 149-163.

74. G. Mittag-Leffler, Weierstrass, Acta Math. 21 (1897), 79-82.

75. __ Die ersten 40 Jahre des Lebens von Weierstrass, Acta Math. 39 (1923), 1-57.

76. __ Weierstrass et Sonja Kowalewsky, Acta Math. 39 (1923), 133-198.

77. A. F. Monna, The concept of function in the 19th and 20th centuries, in particular with regard to the discussions between Baire, Borel and Lebesgue, Arch. Hist. Exact Sci. 9 (1972), 57-84.

78. Dirichlet's principle. A mathematical comedy of errors and its influence on the development of analysis, Oosthoek, Scheltema \& Holkema, Utrecht, 1975.

79. J. Naas and K. Schröder, (eds.), Der Begriff des Raumes in der Geometrie. Bericht von der Riemann-Tagung des Forschungsinstituts für Mathematik, Schriftenreihe des Forschungsinstituts für Mathematik, Heft 1, Akademie-Verlag, Berlin, 1957. 
80. E. Neuenschwander, Casoratis Gespräche mit Kronecker und Weierstrass in Berlin im Jahre 1864, preprint: History of Science Department, University of Aarhus, Aarhus, 1977.

81. The Casorati-Weierstrass Theorem (Studies in the history of complex function theory. I), Historia Math. 5 (1978), 139-166.

82. __ Der Nachlaß von Casorati (1835-1890) in Pavia, Arch. Hist. Exact Sci. 19 (1978), $1-89$.

83. Liemann's example of a continuous, 'nondifferentiable' function, Math. Intelligencer 1 (1978), 40-44.

84. Augustin Cauchy: Ein Wendepunkt in der Geschichte der Analysis, Proceedings Bicentennial Congress Wiskundig Genootschap. II = Math. Centre Tracts 101 (1979), 275-294 = Nieuw Arch. Wisk. (3) 27 (1979), 50-69.

85. _ Riemann und das "Weierstraßsche" Prinzip der analytischen Fortsetzung durch Potenzreihen, Jahresber. Deutsch. Math.-Verein. 82 (1980), 1-11.

86. L_ Lettres de Bernhard Riemann à sa famille, Cahiers du Séminaire d'Histoire des Mathématiques 2 (1981), 85-131.

87. _ Uber die Wechselwirkungen zwischen der französischen Schule, Riemann und Weierstrass. Eine Ubersicht mit zwei Quellenstudien,Arch. Hist. Exact Sci. 24 (1981), 221-255.

88. M. Noether, Zu F. Klein's Schrift “Ueber Riemann's Theorie der algebraischen Functionen", Zeitschrift für Mathematik und Physik 27 (1882), Historisch-literarische Abtheilung, 201-206.

89. H. Poincaré, L'oeuvre mathématique de Weierstrass, Acta Math. 22 (1899), 1-18.

90. A. Pringsheim, Zur Geschichte des Taylorschen Lehrsatzes, Biblio. Math. (3) 1 (1900), 433-479.

91. V. Puiseux, Recherches sur les fonctions algébriques, J. Math. Pures Appl. 15 (1850), 365-480; German translation: V. Puiseux's Untersuchungen über die algebraischen Functionen dargestellt von Hermann Fischer, Schmidt, Halle, 1861, pp. 1-126.

92. Nouvelles recherches sur les fonctions algébriques, J. Math. Pures Appl. 16 (1851), 228-240; German translation: V. Puiseux's Untersuchungen über die algebraischen Functionen dargestellt von Hermann Fischer, Schmidt, Halle, 1861, pp. 127-143.

93. B. Riemann, Bernhard Riemann's Gesammelte Mathematische Werke und Wissenschaftlicher Nachlass. Herausgegeben unter Mitwirkung von Richard Dedekind von Heinrich Weber, 1st ed., Teubner, Leipzig, 1876; 2nd ed., Teubner, Leipzig, 1892, Reprint: Dover, New York, 1953.

94. , Bernhard Riemann's Gesammelte Mathematische Werke. Nachträge. Herausgegeben von M. Noether und W. Wirtinger, Teubner, Leipzig, 1902, Reprint: Dover, New York, 1953.

95. Grundlagen für eine allgemeine Theorie der Functionen einer veränderlichen complexen Grösse, Inauguraldissertation, Göttingen, 1851 = [93], 2nd ed., 3-48.

96. [93], 2nd ed., 88-144.

97. __ Beweis des Satzes, dass eine einwerthige mehr als 2 nfach periodische Function von $n$ Veränderlichen unmöglich ist (Auszug aus einem Schreiben Riemanns an Herrn Weierstrass vom 26. October 1859), J. Reine Angew. Math. 71 (1870), 197-200 = [93], 2nd ed., 294-297.

98. __ Partielle Differentialgleichungen und deren Anwendung auf physikalische Fragen. Vorlesungen von Bernhard Riemann. Für den Druck bearbeitet und herausgegeben von $K$. Hattendorff, 1st ed., Vieweg, Braunschweig, 1869.

99. Schwere, Elektricität und Magnetismus. Nach den Vorlesungen von Bernhard Riemann bearbeitet von Karl Hattendorff, Rümpler, Hannover, 1876.

100. __ Elliptische Functionen. Vorlesungen von Bernhard Riemann. Mit Zusätzen herausgegeben von Hermann Stahl, Teubner, Leipzig, 1899.

101. Theorie der Functionen complexer Variabeln. Vorlesung des Prof. Riemann. Göttingen, Sommersemester 1861; lecture notes taken by E. Abbe formerly in the possession of G. Thieme, Cod. MS: Riemann $32^{c}$, Niedersächsische Staats- und Universitätsbibliothek Göttingen.

Theorie complexer Functionen. Im Sommersemester 1861, 4stündig vorgetragen von B. Riemann;lecture notes taken by $\mathbf{H}$. Hankel [?] formerly in the possession of G. Thieme, Cod. MS: Riemann $32^{\mathrm{g}}$, Niedersächsische Staats- und Universitätsbibliothek Göttingen. 
103. , Theorie der Functionen einer complexen Größe. Vorgetragen von Prof. Riemann. Göttingen, Sommer 1861. Winter 1861/62. Friedrich Prym, Doctor phil.; lithographie: Friedr. Umlauft. Vind. 1865. Available at: Institut Mittag-Leffler, Djursholm, Sweden or University of Illinois at Urbana-Champaign, U.S.A.

104. Letters to the family, Cod. MS: Nachlaß Bernhard Riemann, Staatsbibliothek

Preußischer Kulturbesitz, Berlin.

105. C. Runge, Persönliche Erinnerungen an Karl Weierstraß, Jahresber. Deutsch. Math.Verein. 35 (1926), 175-179.

106. E. Schering, Gesammelte Mathematische Werke, vol. 2, Mayer \& Müller, Berlin, 1909.

107. __ Bernhard Riemann zum Gedächtniss, Nachrichten von der K. Gesellschaft der Wissenschaften und der Georg-Augusts-Universität aus dem Jahre 1867, 305-314 = [106], 161168.

108. __ Zum Gedächtniss an B. Riemann, [106], 367-383, 434-447.

109. L. Schlesinger, Über Gauss' Arbeiten zur Funktionentheorie, [39], vol. 10, pt. 2, Abh. 2.

110. H. A. Schwarz, Ueber einige Abbildungsaufgaben, J. Reine Angew. Math. 70 (1869), 105-120.

111. S. L. Segal, Riemann's example of a continuous "nondifferentiable" function continued, Math. Intelligencer 1 (1978), 81-82.

112. I. Z. Shtokalo (ed.), Istoriya otechestvennoi matematiki, Kiev, 1966-.

113. A. Speiser, Naturphilosophische Untersuchungen von Euler und Riemann, J. Reine Angew. Math. 157 (1927), 105-114.

114. J.-L. Verley, Les fonctions analytiques, Jean Dieudonné, Abrégé d'histoire des mathématiques 1700-1900, Hermann, Paris, 1978, vol. 1, pp. 129-163.

115. J. L. Walsh, History of the Riemann mapping theorem, Amer. Math. Monthly 80 (1973), 270-276.

116. K. Weierstrass, Zur Theorie der Abelschen Functionen, J. Reine Angew. Math. 47 (1854), 289-306 = Math. Werke, vol. 1, Mayer \& Müller, Berlin, 1894, pp. 133-152.

117. __ Theorie der Abel'schen Functionen, J. Reine Angew. Math. 52 (1856), 285-380; excerpt: Math. Werke, vol. 1, Mayer \& Müller, Berlin, 1894, pp. 297-356.

118. _ Zur Functionenlehre, Monatsberichte der Königlich Preussischen Akademie der Wissenschaften zu Berlin, Aus dem Jahre 1880, pp. 719-743 = Math. Werke, vol. 2, Mayer \& Müller, Berlin, 1895, pp. 201-230.

119. __ Darstellung einer analytischen Function einer complexen Veränderlichen, deren absoluter Betrag zwischen zwei gegebenen Grenzen liegt, paper written in 1841, Math. Werke, vol. 1, Mayer \& Müller, Berlin, 1894, pp. 51-66.

120. _ Zur Theorie der Potenzreihen, paper written in 1841, Math. Werke, vol. 1, Mayer \& Müller, Berlin, 1894, pp. 67-74.

121. __ Definition analytischer Functionen einer Veränderlichen vermittelst algebraischer Differentialgleichungen. (Auszug aus einer im Jahre 1842 verfassten, bisher nicht veröffentlichten Abhandlung), Math. Werke, vol. 1, Mayer \& Müller, Berlin, 1894, pp. 75-85.

122. __ Über das sogenannte Dirichlet'sche Princip. (Gelesen in der Königl. Akademie der Wissenschaften am 14. Juli 1870.), Math. Werke, vol. 2, Mayer \& Müller, Berlin, 1895, pp. 49-54.

123. __ Über continuirliche Functionen eines reellen Arguments, die für keinen Werth des letzteren einen bestimmten Differentialquotienten besitzen. (Gelesen in der Königl. Akademie der Wissenschaften am 18. Juli 1872.), Math. Werke, vol. 2, Mayer \& Müller, Berlin, 1895, pp. 71-74.

124. __ Aus einem bisher noch nicht veröffentlichten Briefe an Herrn Professor Schwarz, vom 3. October 1875, Math. Werke, vol. 2, Mayer \& Müller, Berlin, 1895, pp. 235-244.

125. Vorlesungen über die Theorie der Abelschen Transcendenten von Karl Weierstrass.

Bearbeitet von G. Hettner und J. Knoblauch, Math. Werke, vol. 4, Mayer \& Müller, Berlin, 1902.

126. 199-225.

127. Briefe von K. Weierstrass an Paul du Bois-Reymond, Acta Math. 39 (1923),

128. Anwendungen der Theorie der elliptischen Functionen auf Probleme der Geometrie und Mechanik von Prof. Dr. Weierstraß. 1875. Sommer. Berlin, 1875; lecture notes formerly in the possession of G. Thieme, Cod. MS: Bibliothek der Sektion Mathematik der Humboldt-Universität zu Berlin. 
129. Ausgewählte Kapitel aus der Functionenlehre. Vorlesungen von Professor $K$. Weierstrass. Sommer-Semester 1886; lecture notes formerly in the possession of G. Thieme, Cod. MS: Bibliothek der Sektion Mathematik der Humboldt-Universität zu Berlin.

130. Correspondence with H. A. Schwarz. 1866-1893, Cod. MS: Nachlass Schwarz, Akademie der Wissenschaften der DDR, Zentrales Akademie-Archiv, Berlin. Typewritten copy: Institut Mittag-Leffler, Djursholm, Sweden.

131. A. Weil, Elliptic functions according to Eisenstein and Kronecker, Springer, Berlin, Heidelberg and New York, 1976.

132. Riemann, Betti and the birth of topology, Arch. Hist. Exact Sci. 20 (1979), 91-96.

Department of Mathematics, University of Zurich, Zurich, SwitzerLand 
